\title{
STUDIES IN CIRRHOSIS OF THE LIVER. I. RELATIONSHIP BETWEEN PLASMA VOLUME, PLASMA PROTEIN CON- CENTRATIONS AND TOTAL CIRCULATING PROTEINS
}

\author{
By GLENN I. HILLER, ELSTON R. HUFFMAN, AND STANLEY LEVEY
}

(From the Department of Medicine, the Wayne County General Hospital and Infirmary, Eloise,
Michigan, and the Department of Physiological Chemistry, Wayne University
College of Medicine, Detroit)

(Received for publication July 22, 1948)

\section{INTRODUCTION}

Addis, Poo and Lew (1) aptly demonstrated the importance of the liver as a storage place for protein substances. The extensive studies of Whipple and his associates $(2,3)$ allowed some insight into the magnitude of this protein storage and its availability during time of need. It also seems well established that the liver is the principal site of formation of albumin and fibrinogen and to a lesser extent of globulin (4-10). In the presence of severe hepatic disease such as advanced cirrhosis, the functions of protein synthesis and storage are presumably inhibited and this inhibition is reflected by alterations in the various protein concentrations in the plasma. Supporting this concept are the observations $(4,5)$ which correlated the fibrinogen content of the blood with the degree of liver injury. Similarly, hypoalbuminemia has been established as a characteristic laboratory finding in patients with far advanced cirrhosis of the liver $(6,7)$. Plasma protein concentrations cannot, however, be used as an index for total circulating proteins or plasma volume $(11,12)$. It has already been shown that the plasma volume may be elevated in patients with cirrhosis of the liver (13). In a previous communication (14), data were presented from patients with cirrhosis of the liver, illustrating normal values for total circulating proteins despite the presence of low protein concentrations in the serum. The purpose of this communication is to record further data concerned with the plasma volume and the quantitative estimation of the various plasma proteins in patients with far advanced Laennec's cirrhosis of the liver.

\section{MATERIAL AND METHODS}

Twelve patients were chosen for this study. At the onset of investigation each patient exhibited edema, ascites, anemia, hepatomegaly, spider angiomata, and evidence of protein and multiple vitamin deficiency. Patients with jaundice were excluded from the study. Biopsy specimens from the liver, obtained by means of peritoneoscopy from 10 of the patients, were consistent with the impression of far advanced Laennec's cirrhosis. The presence of complicating disease was excluded by means of venous pressure determinations, circulation times, electrocardiograms, renal function tests and roentgenograms of the entire gastrointestinal tract and chest. All patients were men and ranged in age from 38 to 67 years. The average age for the entire group was 49.7 years.

Laboratory tests including hippuric acid excretion (intravenous procedure), bromsulfthalein excretion $(5 \mathrm{mg}$. per kilogram of body weight), prothrombin time, cephalin-cholesterol flocculation and quantitative thymol turbidity were repeated at approximately biweekly intervals. As far as possible these laboratory procedures were obtained within 48 hours before plasma volumes and protein concentrations were determined.

Plasma volumes were determined in the fasting state at bed rest according to the method of Gibson and Evans (15) as modified by Gibson and Evelyn (16). Dye free samples of serum obtained before the injection of T-1824 were used as control readings. Fifteen minutes was found sufficient time to permit thorough mixing of the dye. Plasma volume was finally estimated by extrapolation of the time-concentration curve of the dye. Predicted plasma volumes were estimated according to height (17). Total blood volume was calculated from the simultaneous determination of the plasma volume and the venous hematocrit according to the formula (18) :

$$
\frac{\text { Plasma volume }}{100-\text { hematocrit }} \times 100=\text { blood volume. }
$$

The venous hematocrit was determined according to the method of Wintrobe modified by the use of a $4 \mathrm{ml}$. capacity tube.

Total protein and albumin were determined according to the method of Howe (19) as modified by the use of Conway cells for the estimation of ammonia nitrogen (20). Fibrinogen was determined by conversion to fibrin (21) and, after digestion, the estimation of fibrin nitrogen by means of the Conway cell procedure. All blood samples for nitrogen determinations, hematocrits and plasma volumes were obtained simultaneously.

During the period of observation each patient was maintained on a daily diet in excess of 3000 calories, 
120 or more grams of protein, moderately low in fat and containing approximately 2.7 grams of sodium chloride. Dietary therapy was augmented by vitamin supplements and, in some patients at the beginning of the study, by choline chloride and yeast. In a very few instances protein hydrolysates were given for a short period of time. For approximately the first half of the period of observation each patient received ammonium chloride, 6 grams daily for three days, followed by the administration of $2 \mathrm{ml}$. of mercupurin or mercuhydrin either intra- venously or intramuscularly. After a three day rest period this procedure was repeated. For reasons to be discussed it was felt that diuresis in this manner did not appreciably influence the plasma volume. All patients were considered semi-ambulatory.

\section{RESULTS}

Persistently abnormal results for thymol turbidity, cephalin-cholesterol flocculation, hippuric

TABLE I

Correlated data obtained from observations on plasma volume, blood volume, serum protein concentrations and total circulating proteins in 12 patients with advanced Laennec's cirrhosis of the liver

\begin{tabular}{|c|c|c|c|c|c|c|c|c|c|c|c|}
\hline Day & Weight & $\begin{array}{l}\text { Plasma } \\
\text { volume }\end{array}$ & $\begin{array}{l}\text { Hemato- } \\
\text { crit } \\
\text { (Average) }\end{array}$ & $\begin{array}{l}\text { Total } \\
\text { protein }\end{array}$ & Albumin & Globulin & $\underset{\text { brinogen }}{\mathrm{Fi}-}$ & $\begin{array}{l}\text { Total } \\
\text { circu- } \\
\text { lating } \\
\text { protein }\end{array}$ & $\begin{array}{c}\text { Total } \\
\text { circu- } \\
\text { lating } \\
\text { albumin }\end{array}$ & $\begin{array}{c}\text { Total } \\
\text { circu- } \\
\text { lating } \\
\text { globulin }\end{array}$ & $\begin{array}{c}\text { Total } \\
\text { circu- } \\
\text { lating } \\
\text { fibrinogen }\end{array}$ \\
\hline $\begin{array}{c}\text { J. C. } \\
1 \\
12 \\
32 \\
46 \\
56 \\
63 \\
88 \\
125 \\
179 \\
217 \\
245 \\
259\end{array}$ & $\begin{array}{l}\text { kg. } \\
66.3^{*} \\
68.1 \\
66.3 \\
66.8 \\
68.1 \\
68.4 \\
70.4 \\
71.3 \\
65.9 \\
62.2 \\
64.7\end{array}$ & $\begin{array}{c}m l . \\
2750^{*} \\
2630 \\
3740 \\
5010 \\
5130 \\
5180 \\
4910 \\
4350 \\
4250 \\
5540 \\
5150 \\
5080 \\
4980\end{array}$ & $\begin{array}{l}38.0 \\
40.0 \\
36.5 \\
38.5 \\
35.5 \\
32.2 \\
41.0 \\
38.0 \\
39.0 \\
39.0 \\
40.0 \\
39.0\end{array}$ & $\begin{array}{c}\mathrm{gm./} \\
100 \mathrm{ml} . \\
6.00 \dagger \\
5.14 \\
5.70 \\
6.80 \\
6.70 \\
6.01 \\
6.95 \\
6.59 \\
6.83 \\
7.01 \\
7.00 \\
6.40 \\
6.37\end{array}$ & $\begin{array}{c}\mathrm{gm./} \\
100 \mathrm{ml} \\
4.00 \dagger \\
2.23 \\
2.83 \\
3.20 \\
3.10 \\
4.30 \\
3.22 \\
3.52 \\
3.78 \\
4.05 \\
3.25 \\
4.60 \\
3.59\end{array}$ & $\begin{array}{c}\mathrm{gm} . / \\
100 \mathrm{ml} . \\
2.00 \dagger \\
2.91 \\
2.86 \\
3.60 \\
3.60 \\
1.71 \\
3.73 \\
3.07 \\
3.05 \\
2.96 \\
3.75 \\
1.80 \\
2.78\end{array}$ & $\begin{array}{r}m g . / \\
100 \text { ml. } \\
\\
365 \\
246 \\
170 \\
168 \\
113 \\
505 \\
235 \\
296 \\
234 \\
189 \\
72 \\
164\end{array}$ & $\begin{array}{l}\text { grams } \\
165.0 \ddagger \\
135.2 \\
213.2 \\
340.9 \\
343.7 \\
311.3 \\
341.2 \\
286.7 \\
290.3 \\
388.4 \\
360.5 \\
325.1 \\
317.2\end{array}$ & $\begin{array}{c}\text { grams } \\
110.0 \ddagger \\
58.6 \\
105.9 \\
160.3 \\
159.0 \\
222.7 \\
158.1 \\
153.1 \\
160.7 \\
224.4 \\
167.4 \\
233.7 \\
178.8\end{array}$ & $\begin{array}{c}\text { grams } \\
55.0 \ddagger \\
76.6 \\
107.3 \\
180.4 \\
184.7 \\
88.6 \\
183.1 \\
133.6 \\
129.6 \\
164.0 \\
193.1 \\
91.4 \\
138.4\end{array}$ & $\begin{array}{c}\text { grams } \\
5.5 \ddagger \\
9.6 \\
9.2 \\
8.5 \\
8.6 \\
5.9 \\
24.7 \\
10.2 \\
12.5 \\
12.9 \\
9.7 \\
3.6 \\
8.1\end{array}$ \\
\hline $\begin{array}{c}\text { T. M. } \\
1 \\
15 \\
28 \\
45 \\
59 \\
73 \\
87 \\
107 \\
147\end{array}$ & $\begin{array}{l}74.0^{*} \\
70.9 \\
61.8 \\
59.5 \\
65.4 \\
57.2 \\
60.9 \\
61.3 \\
62.9 \\
65.6\end{array}$ & $\begin{array}{l}2970^{*} \\
3910 \\
3460 \\
4820 \\
4050 \\
3120 \\
3830 \\
3840 \\
4010 \\
3380\end{array}$ & $\begin{array}{l}39.0 \\
40.5 \\
36.0 \\
33.5 \\
36.0 \\
34.5 \\
29.0 \\
33.0 \\
32.0\end{array}$ & $\begin{array}{l}3.54 \\
5.00 \\
5.80 \\
5.44 \\
5.75 \\
5.55 \\
4.25 \\
5.60 \\
5.09\end{array}$ & $\begin{array}{l}1.59 \\
\overline{3.46} \\
2.14 \\
2.22 \\
2.26 \\
1.49 \\
2.53\end{array}$ & $\begin{array}{l}1.95 \\
2.34 \\
3.30 \\
3.53 \\
3.29 \\
2.76 \\
2.56\end{array}$ & $\begin{array}{l}188 \\
208 \\
346 \\
344 \\
530 \\
415 \\
472 \\
457 \\
425\end{array}$ & $\begin{array}{l}178.2 \ddagger \\
138.4 \\
173.0 \\
279.6 \\
220.3 \\
179.4 \\
212.6 \\
163.2 \\
224.6 \\
172.0\end{array}$ & $\begin{array}{c}118.8 \ddagger \\
62.2 \\
\overline{166.8} \\
86.7 \\
69.3 \\
86.6 \\
57.2 \\
\overline{85.5}\end{array}$ & $\begin{array}{c}59.4 \ddagger \\
76.2 \\
\overline{112.8} \\
133.6 \\
111.1 \\
126.0 \\
106.0 \\
\overline{86.5}\end{array}$ & $\begin{array}{l}5.9 \ddagger \\
7.3 \\
7.2 \\
16.7 \\
13.9 \\
16.5 \\
15.8 \\
18.1 \\
18.3 \\
14.3\end{array}$ \\
\hline $\begin{array}{c}\text { C. P. } \\
1 \\
25 \\
84\end{array}$ & $\begin{array}{l}73.6^{*} \\
72.5 \\
71.3\end{array}$ & $\begin{array}{l}3080^{*} \\
3480 \\
3310 \\
2900\end{array}$ & $\begin{array}{l}40 \\
48\end{array}$ & $\begin{array}{l}6.28 \\
6.90 \\
7.59\end{array}$ & $\begin{array}{l}2.49 \\
3.48 \\
4.82\end{array}$ & $\begin{array}{l}3.79 \\
3.42 \\
2.77\end{array}$ & $\frac{492}{283}$ & $\begin{array}{l}184.8 \ddagger \\
218.5 \\
228.4 \\
220.1\end{array}$ & $\begin{array}{c}123.2 \ddagger \\
86.6 \\
115.2 \\
139.8\end{array}$ & $\begin{array}{c}61.6 \ddagger \\
131.9 \\
113.2 \\
80.3\end{array}$ & 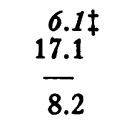 \\
\hline $\begin{array}{r}\text { F. P. } \\
1 \\
22 \\
61 \\
92 \\
110\end{array}$ & $\begin{array}{l}67.7^{*} \\
65.9 \\
67.9 \\
64.5 \\
61.8 \\
60.4\end{array}$ & $\begin{array}{l}2778^{*} \\
4820 \\
4410 \\
4460 \\
4040 \\
3965\end{array}$ & $\begin{array}{l}32 \\
33 \\
35 \\
32 \\
32\end{array}$ & $\begin{array}{l}4.99 \\
5.23 \\
6.27 \\
6.82\end{array}$ & $\begin{array}{l}1.82 \\
3.68 \\
2.83 \\
2.74 \\
2.27\end{array}$ & $\begin{array}{l}3.17 \\
2.40 \\
3.53 \\
4.55\end{array}$ & $\begin{array}{l}410 \\
532 \\
452 \\
315 \\
315\end{array}$ & $\begin{array}{c}166.7 \ddagger \\
240.5 \\
- \\
233.2 \\
253.3 \\
270.4\end{array}$ & $\begin{array}{r}111.1 \ddagger \\
87.7 \\
162.3 \\
126.2 \\
110.7 \\
90.0\end{array}$ & $\begin{array}{c}55.6 \ddagger \\
152.8 \\
107.0 \\
142.6 \\
180.4\end{array}$ & $\begin{array}{l}5.5 \ddagger \\
19.7 \\
23.4 \\
20.1 \\
12.7 \\
12.4\end{array}$ \\
\hline $\begin{array}{r}\text { J. G. } \\
1 \\
15 \\
33 \\
43 \\
147 \\
209 \\
235\end{array}$ & $\begin{array}{l}67.7^{*} \\
71.3 \\
68.1 \\
68.1 \\
71.3 \\
73.1 \\
74.3 \\
71.3\end{array}$ & $\begin{array}{l}2805^{*} \\
4890 \\
4260 \\
4150 \\
4470 \\
4835 \\
-\overline{4880}\end{array}$ & $\begin{array}{l}33.5 \\
35.7 \\
38.7 \\
38.5 \\
41 \\
37 \\
38\end{array}$ & $\begin{array}{l}5.26 \\
7.48 \\
7.60 \\
7.31 \\
7.04 \\
6.13 \\
6.58\end{array}$ & $\begin{array}{l}2.30 \\
3.21 \\
3.60 \\
3.58 \\
4.65 \\
3.26 \\
3.40\end{array}$ & $\begin{array}{l}2.96 \\
4.27 \\
4.00 \\
3.73 \\
2.39 \\
2.87 \\
3.18\end{array}$ & $\begin{array}{l}202 \\
346 \\
225 \\
322 \\
357 \\
\frac{283}{}\end{array}$ & $\begin{array}{c}168.3 \ddagger \\
257.2 \\
318.7 \\
315.4 \\
326.7 \\
340.4 \\
321.1\end{array}$ & $\begin{array}{l}112.2 \ddagger \\
112.5 \\
136.8 \\
149.4 \\
160.0 \\
224.8 \\
\overline{165.9}\end{array}$ & $\begin{array}{c}56.1 \ddagger \\
144.7 \\
181.9 \\
166.0 \\
166.7 \\
115.6 \\
155.2\end{array}$ & $\begin{array}{r}5.6 \ddagger \\
9.9 \\
14.7 \\
9.3 \\
14.4 \\
17.2 \\
\overline{13.8}\end{array}$ \\
\hline
\end{tabular}

* Predicted normal weight and plasma volume for each patient.

† Accepted minimum normal values for total protein, albumin and globulin concentrations.

$\ddagger$ Minimum normal quantity of total circulating protein, albumin, globulin and fibrinogen for each patient. 
TABLE 1-Continued

\begin{tabular}{|c|c|c|c|c|c|c|c|c|c|c|c|}
\hline Day & Weight & $\begin{array}{l}\text { Plasma } \\
\text { volume }\end{array}$ & $\begin{array}{c}\text { Hemato- } \\
\text { crit } \\
\text { (Average) }\end{array}$ & $\begin{array}{c}\text { Total } \\
\text { protein }\end{array}$ & Albumin & Globulin & $\begin{array}{c}\text { Fi- } \\
\text { brinogen }\end{array}$ & $\begin{array}{c}\text { Total } \\
\text { circu- } \\
\text { lating } \\
\text { protein }\end{array}$ & $\begin{array}{c}\text { Total } \\
\text { circu- } \\
\text { lating } \\
\text { albumin }\end{array}$ & $\begin{array}{c}\text { Total } \\
\text { circu- } \\
\text { lating } \\
\text { globulin }\end{array}$ & $\begin{array}{c}\text { Total } \\
\text { circu- } \\
\text { lating } \\
\text { fibrinogen }\end{array}$ \\
\hline $\begin{array}{r}\text { G. O. } \\
1 \\
3 \\
11 \\
23 \\
36 \\
60 \\
74 \\
85 \\
88 \\
109 \\
122 \\
136 \\
176 \\
192 \\
218 \\
232 \\
276 \\
280\end{array}$ & $\begin{array}{c}\text { kg. } \\
67.7^{*} \\
73.6 \\
- \\
86.3 \\
87.5 \\
82.7 \\
85.9 \\
87.2 \\
81.8 \\
84.3 \\
80.0 \\
90.0 \\
77.7 \\
84.3 \\
80.0 \\
84.5 \\
86.5\end{array}$ & $\begin{array}{c}m l . \\
2750^{*} \\
3375 \\
3450 \\
3320 \\
4620 \\
5530 \\
4960 \\
3950 \\
-790 \\
5190 \\
4250 \\
4620 \\
3940 \\
4100 \\
4000 \\
4040 \\
3905 \\
3820\end{array}$ & $\begin{array}{l}40 \\
39 \\
31 \\
34 \\
36.5 \\
34.5 \\
31.1 \\
33.7 \\
36 \\
37 \\
38 \\
39 \\
38 \\
38 \\
38 \\
35 \\
38 \\
\end{array}$ & $\begin{array}{c}\text { gm.l } \\
100 \mathrm{ml} . \\
\\
6.72 \\
6.42 \\
3.72 \\
5.75 \\
6.44 \\
4.78 \\
6.15 \\
6.84 \\
6.65 \\
5.95 \\
5.76 \\
6.60 \\
5.89 \\
5.88 \\
5.44 \\
5.72 \\
7.72 \\
6.13\end{array}$ & $\begin{array}{c}\mathrm{gm} . / \\
100 \mathrm{ml} . \\
\\
1.48 \\
2.72 \\
1.66 \\
2.83 \\
3.43 \\
2.44 \\
2.54 \\
3.22 \\
1.97 \\
3.83 \\
3.35 \\
2.46 \\
1.14 \\
2.46 \\
2.70 \\
2.26 \\
2.08 \\
2.36\end{array}$ & $\begin{array}{c}\text { gm. } / \text { ml. } \\
\\
5.24 \\
3.70 \\
2.06 \\
2.92 \\
3.01 \\
2.34 \\
3.61 \\
3.62 \\
4.68 \\
2.12 \\
2.41 \\
4.14 \\
4.75 \\
3.42 \\
2.74 \\
3.46 \\
5.64 \\
3.77\end{array}$ & $\begin{array}{c}m g . / \\
100 \mathrm{ml} . \\
\\
359 \\
195 \\
391 \\
283 \\
303 \\
314 \\
376 \\
302 \\
282 \\
472 \\
357 \\
\overline{170} \\
378 \\
375 \\
425 \\
315 \\
440\end{array}$ & $\begin{array}{l}\text { grams } \\
165.0 \ddagger \\
226.8 \\
221.5 \\
123.5 \\
265.7 \\
356.1 \\
237.1 \\
242.9 \\
- \\
318.5 \\
308.8 \\
244.8 \\
304.9 \\
232.1 \\
241.1 \\
217.6 \\
231.1 \\
301.4 \\
234.1\end{array}$ & $\begin{array}{c}\text { grams } \\
110.0 \ddagger \\
49.9 \\
93.8 \\
55.1 \\
130.8 \\
189.7 \\
121.0 \\
100.3 \\
\overline{94.3} \\
198.8 \\
142.4 \\
113.6 \\
44.9 \\
100.9 \\
108.0 \\
91.3 \\
81.2 \\
90.1\end{array}$ & $\begin{array}{c}\text { grams } \\
55.0 \ddagger \\
176.9 \\
127.7 \\
68.4 \\
134.9 \\
166.4 \\
116.1 \\
142.6 \\
-\overline{0} \\
224.2 \\
110.0 \\
102.4 \\
191.3 \\
187.2 \\
140.2 \\
109.6 \\
139.8 \\
220.2 \\
144.0\end{array}$ & $\begin{array}{c}\text { grams } \\
5.5 \ddagger \\
12.1 \\
6.7 \\
12.9 \\
13.0 \\
16.7 \\
15.5 \\
14.8 \\
13.5 \\
24.5 \\
15.1 \\
\overline{6} .6 \\
15.4 \\
15.0 \\
17.1 \\
12.3 \\
16.8\end{array}$ \\
\hline $\begin{array}{r}\text { A. D. } \\
1 \\
8 \\
12 \\
22 \\
35 \\
43 \\
64 \\
78\end{array}$ & $\begin{array}{l}83.1^{*} \\
80.9 \\
86.3 \\
81.6 \\
82.2 \\
84.7 \\
84.3 \\
85.9 \\
-\end{array}$ & $\begin{array}{l}3223^{*} \\
4040 \\
3810 \\
4060 \\
3320 \\
3915 \\
4400 \\
4550 \\
4058\end{array}$ & $\begin{array}{l}44.5 \\
38 \\
44 \\
43 \\
43 \\
42 \\
41 \\
45\end{array}$ & $\begin{array}{l}4.45 \\
5.75 \\
5.18 \\
6.02 \\
5.64 \\
5.00 \\
5.94\end{array}$ & $\begin{array}{l}2.45 \\
3.37 \\
3.02 \\
3.02 \\
2.36 \\
-7.35 \\
3.30\end{array}$ & $\begin{array}{l}2.00 \\
2.38 \\
2.16 \\
3.00 \\
3.28 \\
-\overline{2.65} \\
2.64\end{array}$ & $\begin{array}{l}315 \\
189 \\
189 \\
312 \\
315 \\
126 \\
420\end{array}$ & $\begin{array}{l}193.4 \ddagger \\
179.8 \\
219.1 \\
210.3 \\
199.9 \\
220.8 \\
\overline{227.5} \\
241.0\end{array}$ & $\begin{array}{c}128.9 \ddagger \\
99.0 \\
128.4 \\
122.6 \\
100.3 \\
92.4 \\
106.9 \\
133.9\end{array}$ & $\begin{array}{r}64.5 \ddagger \\
80.8 \\
90.7 \\
87.7 \\
99.6 \\
128.4 \\
120.6 \\
107.1\end{array}$ & $\begin{array}{c}6.4 \ddagger \\
12.7 \\
7.2 \\
7.6 \\
10.3 \\
12.3 \\
\overline{5.7} \\
17.0\end{array}$ \\
\hline $\begin{array}{c}\text { H. R. } \\
1 \\
14 \\
15 \\
28 \\
49 \\
63\end{array}$ & $\begin{array}{c}74.0^{*} \\
81.8 \\
74.0 \\
78.6 \\
70.4 \\
80.2\end{array}$ & $\begin{array}{l}2981^{*} \\
2622 \\
2278 \\
3320 \\
3900 \\
3820 \\
3990\end{array}$ & $\begin{array}{l}37 \\
40 \\
40.5 \\
38 \\
39 \\
38\end{array}$ & $\begin{array}{l}6.55 \\
5.93 \\
6.57 \\
6.25 \\
7.10 \\
6.61\end{array}$ & $\begin{array}{l}1.40 \\
1.21 \\
2.33 \\
1.48 \\
1.32 \\
2.88\end{array}$ & $\begin{array}{l}5.15 \\
4.72 \\
4.24 \\
4.77 \\
5.78 \\
3.73\end{array}$ & $\begin{array}{l}127 \\
99.8 \\
255 \\
238 \\
169 \\
217\end{array}$ & $\begin{array}{l}178.8 \ddagger \\
171.7 \\
135.1 \\
218.2 \\
243.7 \\
271.2 \\
263.7\end{array}$ & $\begin{array}{r}119.2 \ddagger \\
36.7 \\
27.6 \\
77.3 \\
57.7 \\
50.4 \\
114.9\end{array}$ & $\begin{array}{l}59.6 \ddagger \\
135.0 \\
107.5 \\
140.9 \\
186.0 \\
220.8 \\
148.8\end{array}$ & $\begin{array}{l}5.9 \ddagger \\
3.3 \\
2.2 \\
8.4 \\
9.2 \\
6.4 \\
8.6\end{array}$ \\
\hline $\begin{array}{c}\text { C. W. } \\
1 \\
10 \\
31 \\
58 \\
62 \\
94\end{array}$ & $\begin{array}{l}74.0^{*} \\
\text { cast } \\
\text { cast } \\
\text { cast } \\
61.5 \\
61.5 \\
63.1 \\
\end{array}$ & $\begin{array}{l}2987^{*} \\
2920 \\
3005 \\
3440 \\
2940 \\
3270 \\
3030 \\
\end{array}$ & $\begin{array}{l}40 \\
40 \\
40 \\
38 \\
38 \\
39 \\
\end{array}$ & $\begin{array}{l}5.22 \\
6.72 \\
7.72 \\
7.05 \\
7.72 \\
6.83 \\
\end{array}$ & $\begin{array}{l}2.16 \\
3.85 \\
1.25 \\
4.54 \\
4.30 \\
3.96 \\
\end{array}$ & $\begin{array}{l}3.06 \\
2.87 \\
6.47 \\
2.51 \\
3.42 \\
2.87 \\
\end{array}$ & $\begin{array}{l}299 \\
378 \\
236 \\
441 \\
520 \\
- \\
\end{array}$ & $\begin{array}{l}179.2 \ddagger \\
152.4 \\
201.9 \\
265.6 \\
207.2 \\
252.4 \\
206.8 \\
\end{array}$ & $\begin{array}{c}119.5 \ddagger \\
63.1 \\
115.7 \\
43.0 \\
133.4 \\
140.6 \\
119.9 \\
\end{array}$ & $\begin{array}{r}59.7 \ddagger \\
89.3 \\
86.2 \\
222.6 \\
73.8 \\
111.8 \\
86.9 \\
\end{array}$ & $\begin{array}{c}5.9 \ddagger \\
8.7 \\
11.3 \\
8.1 \\
12.9 \\
17.0\end{array}$ \\
\hline $\begin{array}{r}\text { J. R. } \\
1 \\
58 \\
106 \\
142 \\
170 \\
184 \\
205\end{array}$ & $\begin{array}{l}70.9^{*} \\
84.5 \\
82.0 \\
81.8 \\
83.6 \\
82.5 \\
83.6 \\
82.2\end{array}$ & $\begin{array}{l}2926^{*} \\
5270 \\
4980 \\
4740 \\
4500 \\
\overline{-} \\
4440\end{array}$ & $\begin{array}{l}24 \\
36 \\
36 \\
40 \\
39 \\
36 \\
\end{array}$ & $\begin{array}{l}6.44 \\
5.64 \\
3.41 \\
5.80 \\
6.40 \\
8.62 \\
-\end{array}$ & $\begin{array}{l}1.52 \\
2.08 \\
2.08 \\
2.83 \\
2.83 \\
-\end{array}$ & $\begin{array}{l}4.92 \\
1.33 \\
3.72 \\
3.57 \\
5.79 \\
-\end{array}$ & $\begin{array}{l}163 \\
220 \\
284 \\
189 \\
252 \\
126 \\
-\end{array}$ & $\begin{array}{l}175.5 \ddagger \\
339.4 \\
280.9 \\
161.6 \\
261.0 \\
= \\
=\end{array}$ & $\begin{array}{c}117.0 \ddagger \\
80.1 \\
\overline{96.6} \\
93.6 \\
= \\
=\end{array}$ & $\begin{array}{c}58.5 \ddagger \\
259.3 \\
\overline{63.0} \\
167.4 \\
= \\
=\end{array}$ & $\begin{array}{c}5.8 \ddagger \\
8.5 \\
10.9 \\
13.4 \\
8.5 \\
= \\
=\end{array}$ \\
\hline $\begin{array}{r}\text { E. D. } \\
1 \\
9 \\
23 \\
36\end{array}$ & $\begin{array}{l}73.1^{*} \\
70.9 \\
70.9 \\
72.2 \\
72.7\end{array}$ & $\begin{array}{l}3003^{*} \\
3130 \\
4230 \\
3950 \\
3620\end{array}$ & $\begin{array}{l}40 \\
44 \\
45 \\
44\end{array}$ & $\begin{array}{r}6.12 \\
7.25 \\
7.94 \\
6.78\end{array}$ & $\begin{array}{l}3.77 \\
2.46 \\
3.78 \\
1.70\end{array}$ & $\begin{array}{l}2.35 \\
4.79 \\
4.16 \\
5.08\end{array}$ & $\begin{array}{l}409 \\
365 \\
208 \\
567 \\
\end{array}$ & $\begin{array}{l}180.1 \ddagger \\
191.6 \\
306.7 \\
313.6 \\
245.4\end{array}$ & $\begin{array}{r}120.1 \ddagger \\
118.0 \\
104.1 \\
149.3 \\
61.5\end{array}$ & $\begin{array}{c}60.0 \ddagger \\
73.6 \\
202.6 \\
164.3 \\
183.9\end{array}$ & $\begin{array}{c}6.0 \ddagger \\
12.8 \\
15.4 \\
8.2 \\
20.5\end{array}$ \\
\hline $\begin{array}{c}\text { A. B. } \\
1 \\
15\end{array}$ & $\begin{array}{l}66.3^{*} \\
-\end{array}$ & $\begin{array}{l}2772^{*} \\
2710 \\
2300\end{array}$ & $\begin{array}{l}41 \\
41.5\end{array}$ & $\begin{array}{l}6.65 \\
7.31\end{array}$ & $\begin{array}{l}1.82 \\
3.15\end{array}$ & $\begin{array}{l}4.83 \\
4.16\end{array}$ & $\begin{array}{l}270 \\
315\end{array}$ & $\begin{array}{l}166.3 \ddagger \\
180.2 \\
168.1\end{array}$ & $\begin{array}{c}110.9 \ddagger \\
49.3 \\
72.4\end{array}$ & $\begin{array}{c}55.4 \ddagger \\
130.9 \\
95.7\end{array}$ & $\begin{array}{l}5.5 \ddagger \\
7.3 \\
7.2\end{array}$ \\
\hline
\end{tabular}


acid excretion and bromsulfthalein excretion were found in all patients throughout the study. Prothrombin time returned to normal in all patients soon after the institution of parenteral and oral vitamin $\mathrm{K}$ therapy. The results of these five tests were taken to indicate that persistent liver damage was present in each patient for the duration of the study.

Table I contains the correlated data obtained from observations on plasma volume, serum protein concentrations and total circulating proteins in the 12 patients. Percentage deviation values for the various serum protein concentrations were based on the minimum normal values of 6,4 and 2 grams per $100 \mathrm{ml}$. for total protein, albumin and globulin respectively (22). The minimum normal values for the total circulating proteins in any given patient were obtained by use of these figures and the predicted plasma volume. Thus, any value for the individual total circulating proteins which exceeded the theoretical minimum normal value could be considered within normal limits for the patient.

It is apparent that the vast majority of the individual plasma volumes represent significant elevations above the predicted normal values. In 83 determinations, 68 ( 81.9 per cent) were more than 10 per cent above predicted values. Thirty ( 36.1 per cent) were more than 50 per cent above normal. In one patient (J. C.), nine of 12 determinations were more than 50 per cent above normal. Twelve determinations (14.4 per cent) were within plus-minus 10 per cent of predicted values. The three remaining determinations were more than 10 per cent below normal. Despite fluctuations, sustained elevations in plasma volume were present in most of the patients.

The total blood volume was estimated 79 times. Of these, 60 (75.9 per cent) were more than 10 per cent above predicted values. Eleven (13.9 per cent) were more than 50 per cent above normal. Of the remaining determinations, 14 (17.7 per cent) were considered to be within normal range and five (6.3 per cent) were more than 10 per cent below normal.

Total protein concentration in the serum was determined 84 times on the 12 patients. Of these, 34 ( 40.4 per cent) were below 6 grams per $100 \mathrm{ml}$. Three patients (A. B., C. P., E. D.), accounting for nine determinations, had total protein concen- trations consistently above 6 grams per $100 \mathrm{ml}$. Thus, the remaining nine patients were considered to have had hypoproteinemia either consistently or at some time during the course of their study.

The quantity of total circulating protein was found to be within theoretical normal limits in 69 (86.2 per cent) of 80 determinations. Five patients (C. P., F. P., E. D., A. B., J. G.) had total circulating protein values consistently within the range of normal. These five patients accounted for 19 of the 80 determinations.

Albumin concentration in the serum was determined 82 times. Of these, 75 (91.4 per cent) were below 4 grams per $100 \mathrm{ml}$. Each patient exhibited hypoalbuminemia, as determined by concentration levels, almost consistently throughout his period of study. At no time did eight of the patients reach a normal value for albumin concentration.

The quantity of total circulating albumin was found to be within theoretical normal limits in 32 (41.0 per cent) of 78 determinations. Only one patient (J. G.) had consistently normal values. This patient accounted for six of the determinations.

Globulin concentration in the serum was determined 81 times. In only four instances was the globulin concentration below 2 grams per $100 \mathrm{ml}$. This represented 4.9 per cent of the total number of the determinations.

The quantity of total circulating globulin (77 determinations) was found to exceed the theoretical minimum normal values in every instance.

Fibrinogen concentration was determined 82 times. In 64 ( 78.0 per cent) the concentration was above $200 \mathrm{mg}$. per $100 \mathrm{ml}$. In 75 (94.9 per cent) of 79 determinations, the quantity of total circulating fibrinogen was found to be above the theoretical minimum normal values. One patient (J. C.), at a time when the plasma volume was $5080 \mathrm{ml}$., had a fibrinogen concentration of only $72.5 \mathrm{mg}$. per cent which represented a total circulating value of 3.6 grams. Another patient $(H$. R.) had moderately low values on two occasions; at one time the plasma volume was $2622 \mathrm{ml}$., the fibrinogen concentration $127 \mathrm{mg}$. per cent and the total circulating quantity of fibrinogen 3.3 grams. At another time the plasma volume was $2278 \mathrm{ml}$., the fibrinogen concentration $99.8 \mathrm{mg}$. per cent and the quantity of total circulating fibrinogen 2.2 grams. A third patient (A. D.) accounted for the 
fourth subnormal value. The plasma volume was $4550 \mathrm{ml}$., the fibrinogen concentration $126 \mathrm{mg}$. per cent and the quantity of total circulating fibrinogen 5.7 grams. At no time did any of the patients exhibit hemorrhagic tendencies which could be attributed to subnormal values for fibrinogen.

From these observations it is apparent that the serum protein concentrations alone cannot be used to estimate the quantity of total circulating proteins in patients with advanced Laennec's cirrhosis of the liver. It is also apparent that any estimation of the degree of protein synthesis depends, in part, upon the determination of total circulating quantities rather than concentrations in the serum. Thus, patients with low concentrations of proteins in the plasma may, by virtue of sustained elevations in plasma volume, have total circulating quantities within the limits of normal. These data, based upon the total number of individual determinations, are summarized in Table II.

TABLE II

Tabular listing of the number of individual determinations on 12 patients with advanced Laennec's cirrhosis of the liver showing both numerical and percentile relationship between concentration of proteins and circulating proteins

\begin{tabular}{l|c|c|c}
\hline \hline & $\begin{array}{c}\text { Number } \\
\text { of de- } \\
\text { termi- } \\
\text { nations }\end{array}$ & $\begin{array}{c}\text { Number of } \\
\text { determina- } \\
\text { tions above } \\
\text { minimum } \\
\text { normal value }\end{array}$ & $\begin{array}{c}\text { Per cent of } \\
\text { determina- } \\
\text { tions above } \\
\text { minimum } \\
\text { normal value }\end{array}$ \\
\hline Plasma volume & 83 & $68^{*}$ & 81.9 \\
Total protein concentration & 84 & 50 & 59.6 \\
Total circulating protein & 80 & 69 & 86.2 \\
Albumin concentration & 82 & 7 & 8.6 \\
Total circulating albumin & 78 & 32 & $\mathbf{4 1 . 0}$ \\
Globulin concentration & 81 & 77 & 95.1 \\
Total circulating globulin & 77 & 77 & $\mathbf{1 0 0 . 0}$ \\
Fibrinogen concentration & 82 & 64 & 94.9 \\
Total circulating fibrinogen & 79 & 75 &
\end{tabular}

* Number of plasma volumes more than 10 per cent above predicted values.

Attempts to evaluate response to treatment were limited to seven patients all of whom were studied for more than 90 days. Since results of the four hepatic function tests discussed above could not be correlated with the clinical state of the patient, clinical improvement was based specifically upon disappearance of edema and ascites, return to a clinically normal nutritional state, improved or normal blood count and, finally, ability to remain ambulatory without recurrence of preexisting signs and symptoms. The maintenance of a continued state of improvement while fully ambulatory out- side the hospital was considered an important factor in evaluating prognosis.

Only three patients (J. C., J. G., C. W.) satisfied these criteria for improvement. The first two patients have been observed for four months following discharge from the hospital. The third (C. W.) has remained as a hospital employee. A fourth patient (F. P.), in whom temporary improvement occurred, failed towards the end of the study. Coincident with this failure to maintain an improved state was the demonstration of a filling defect in the stomach. Ability to maintain a quantity of total circulating albumin above predicted minimum values occurred in three of these patients and temporarily in the fourth (F. P.) despite the presence of hypoalbuminemia as estimated by concentrations in the serum. Another patient (J.R.) showed only moderate improvement while in the hospital and has not been adequately followed since discharge. One (G. O.) has shown no improvement over a long period of time and one (T. M.) expired from his disease and complicating bronchopneumonia. These last three patients were not able to maintain a quantity of total circulating albumin above predicted minimum values.

Of the remaining five patients, all of whom were studied for less than 90 days, only two (E. D., C. P.) are making satisfactory progress. One (A. B.) left the hospital before response to treatment could be evaluated. Another (H. R.) expired in severe hepatic decompensation complicated by bronchopneumonia. The fifth (A. D.) expired following a "button" operation performed in another hospital without our knowledge. This patient had entered the hospital with a history of having had 96 abdominal paracenteses during the preceding 12 months. Routine studies revealed the presence of peritoneal tuberculosis complicating the cirrhosis. Despite this complication and the loss of large amounts of albumin in the ascitic fluid, a near normal quantity of total circulating albumin was maintained in the plasma until his demise.

Although this series is small, clinical improvement, based on criteria given above, could be correlated with ability to maintain a quantity of total circulating albumin above predicted minimum values. Since all of the patients exhibited subnormal concentrations of albumin in the serum, this correlation existed only in those who had sustained 
TABLE III

Tabular listing of 12 cases of advanced Laennec's cirrhosis of the liver to illustrate the average per cent deviation from the predicted plasma volume and from the minimum normal values for both concentrations of proteins in the serum and total circulating proteins in individual patients

\begin{tabular}{l|c|c|c|c|c|c|c}
\hline \hline & \multicolumn{3}{|c|}{ Concentrations } & \multicolumn{3}{c}{ Circulating proteins } \\
\cline { 2 - 6 } & P. V. & T. P. & Alb. & Glob. & T. C. P. & T. C. A. & T. C. G. \\
\hline J. C. & +69.5 & +7.6 & -13.1 & +49.2 & +84.5 & +50.2 & +153.1 \\
J. G. & +63.3 & +12.7 & -14.2 & +67.1 & +86.1 & +41.0 & +76.3 \\
C. W. & +3.8 & +14.9 & -16.4 & +76.6 & +19.6 & -14.1 & +87.2 \\
F. P. & +56.1 & -2.8 & -33.3 & +70.6 & +49.5 & +3.8 & +162.0 \\
J. R. & +63.5 & +0.8 & -43.3 & +93.3 & +48.5 & -23.0 & +179.0 \\
A. D. & +24.7 & +9.5 & -29.0 & +29.3 & +10.7 & -13.1 & +58.3 \\
T. M. & +28.7 & -14.7 & -43.9 & +40.9 & +9.9 & -26.1 & +80.8 \\
G. O. & +53.7 & +0.5 & -37.5 & +76.7 & +53.6 & -3.4 & +167.5 \\
E. D. & +24.2 & +17.0 & -26.8 & +104.7 & +46.7 & -9.8 & +160.1 \\
H. R. & +11.4 & +8.3 & -55.7 & +136.5 & +21.5 & -49.0 & +16.5 \\
C. P. & +4.8 & +15.3 & -10.0 & +66.3 & +20.3 & -7.5 & +76.0 \\
A. B. & -9.6 & +16.3 & -37.8 & +124.7 & +4.7 & -45.1 & +104.5 \\
\hline
\end{tabular}

elevations in plasma volume. In most instances wide fluctuations in serum protein concentrations were not present. Three of the four patients who made the greatest degree of improvement possessed high plasma volumes and quantities of total circulating albumin above predicted minimum values throughout most of the study. The fourth patient (C. W.) eventually became able to maintain a normal quantity of total circulating albumin without an appreciable elevation in plasma volume.
Observations relative to the average percentile deviation from the predicted plasma volume and from the minimum normal values for both concentrations and total circulating proteins for each patient are presented in Table III. In most instances fluctuations in plasma volume in any given patient were paralleled by similar fluctuations in the quantity of total circulating protein. This observation is illustrated in Figure 1 which records the data on one of the patients.

\section{DISCUSSION}

The sustained elevations in plasma volume in cirrhotic patients cannot be explained by behavior of the dye. Wide variations in protein concentration do not appreciably affect the optical density of T-1824 (23). In accord with reports elsewhere $(13,24)$, we were unable to demonstrate the presence of the dye in the ascitic fluid as long as one hour after the intravenous injection of large amounts. On the basis that intra-abdominal pressure might act as a barrier preventing diffusion of the dye into the peritoneal cavity, the ascitic fluid was largely removed. Again, the dye failed to appear in the remaining ascitic fluid as long as one hour later under similar conditions. Under cer-

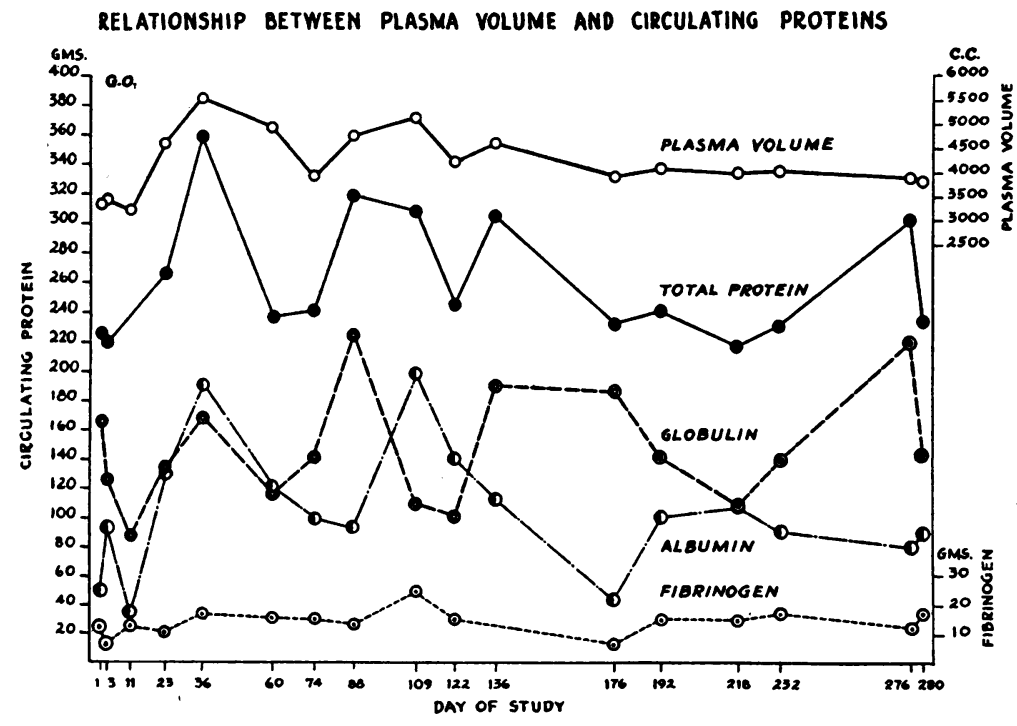

FIG. 1

Predicted normal values for patient G. O. are: Plasma volume, 2750 ml.; total circulating protein, 165 grams; total circulating albumin, 110 grams; total circulating globulin, 55 grams; total circulating fibrinogen, 5.5 grams. 
tain circumstances, however, the dye may appear in the ascitic fluid. One patient developed a distinct blue color in the ascitic fluid after a large number of plasma volume determinations were made with $\mathrm{T}-1824$ in a relatively short period of time. Inspection of the time-concentration curves did not reveal any sudden or unexpected loss of dye from the vascular system in any of the patients. It is undisputed that dye eventually escapes into the interstitial fluid and certainly into the ascitic fluid, but not appreciably so during the time required to perform the plasma volume determination.

Other factors in the cirrhotic patient may contribute to the elevated plasma volume. Hydremic hypovolemia in the severe stages of pernicious anemia and increases in plasma volume in the hypochromic anemias have been reported elsewhere (25). In nearly all instances the patients reported here exhibited at least moderate degrees of anemia and reduced hematocrit values at some time during the course of their study. Inability of the cirrhotic liver to normally inactivate the posterior pituitary antidiuretic factor (26) and to normally inactivate and conjugate estrogens undoubtedly contributes to the elevated plasma volume in certain instances. The relation of the normal and pathologic liver to estrogen metabolism has recently been reviewed (27). The water-retaining effect of estrogens (28) is now well known. The urine of cirrhotic patients with edema has been found to contain a potent antidiuretic factor (29). Recently, a vasodepressor subtance (VDM) of hepatic origin has been shown to appear in the blood of decompensated cirrhotic patients (30). Still more recently, it has been shown that cirrhotics with edema release only very small amounts of sodium into the urine (31). Lastly, it has been suggested that the chief factors responsible for the elevated plasma volume are distension behind the point of portal obstruction and the increased size of the collateral vascular bed required to handle the portal circulation (13).

Reference to the plasma volumes in any given patient in this series reveals no significant or consistent correlation with the presence or absence of anemia, edema or ascites. In the four patients in whom edema and ascites disappeared and, clinically, the nutritional state returned to normal, the plasma volumes remained elevated. Three of these improved patients had unusually high plasma volumes which were sustained throughout the study. Such elevations, in the absence of edema, cannot be explained on the basis of sodium retention, hypoproteinemia or disturbed estrogen metabolism. Since the plasma volume tends to increase in anemic states, anemia probably was a contributing factor in most of these patients. The presence of antidiuretic factors was not investigated but also would seem unlikely as a major cause of the elevation in the absence of edema. The patients reported here exhibited evidence of collateral circulation manifested by hemorrhoids, dilated superficial abdominal veins and esophageal varices. All had large livers and two had large spleens. Since the large liver and extensive collateral vascular bed must add a considerable increment to the capacity of the vascular system, it is suggested that a large portion of the sustained elevation in plasma volume in advanced Laennec's cirrhosis has its basis in this explanation.

Most of these patients received a mercurial diuretic and ammonium chloride at regular intervals during the first half of the study. Although small fluctuations in plasma volume occur during active diuresis, this is a temporary phenomenon and does not influence the sustained increase. Furthermore, inspection of plasma volume curves for each patient before and after diuresis revealed no significant alterations which could be attributed to the use of diuretics.

In some of the patients changes in plasma volume, at a time when hematocrits remained relatively constant, indicated tremendous increases in circulating red cell mass. In this respect it should be emphasized that determination of the circulating red cell mass by means of the plasma volume and hematocrit affords only a rough estimate. A macrocytic anemia was present at one time or another in all of the patients but not consistently so. Bone marrow studies were not obtained on these patients ; however, other studies have indicated that increased erythropoiesis is frequently present in cirrhosis of the liver. Berman et al. (32) reports the consistent change in the bone marrow to be extension of the marrow organ so that active hematopoiesis is found in the shafts of long bones. The bone marrow is of normal or increased cellularity, with normal or increased erythrocytogenesis, regardless of the presence or absence of anemia. 
Hypocellularity of the marrow was considered an unusual finding.

The clinical significance of the serum protein changes has been recently reviewed (33). Concentrations of proteins in the serum cannot, however, be used to estimate total circulating quantities in cirrhotic patients. This is emphasized by the sustained elevations in plasma volumes in the patients reported here. That the quantity of total circulating albumin may be related to prognosis is demonstrated by the findings in four of the patients who improved according to criteria already discussed. Despite low concentrations of albumin in the serum and persistently abnormal hepatic function tests, three of these patients have shown continued improvement and ability to maintain a quantity of total circulating albumin above the theoretical minimum values. The same correlation existed temporarily in a fourth patient. Two of these patients have been under observation for more than 16 months and two for more than nine months. No correlation existed between improvement and the various serum protein concentrations, total circulating protein, total circulating globulin and several hepatic function tests. $\mathrm{Ob}$ servations (34) on the amount of protein lost in the ascitic fluid due to repeated abdominal paracenteses in some of the patients suggested that synthesis of albumin proceeded at an unusually high rate despite low concentrations in the serum and impairment of other liver functions.

Ability to synthesize fibrinogen in normal quantities even in the presence of advanced cirrhosis is also suggested. Apparently, fibrinogen synthesis is one of the last functions to be impaired in progressive cirrhosis of the liver.

\section{SUMMARY}

1. Periodic observations of the plasma volume, blood volume, various serum protein concentrations and total circulating proteins were made on 12 patients with far advanced Laennec's cirrhosis of the liver.

2. Considerable and sustained elevation of the plasma volume was present in most of the patients. Observations on four patients, during the absence of clinical edema and ascites, suggest that the major portion of the elevation in plasma volume is due to hepatomegaly, splenomegaly and the ex- tensive collateral circulation which develops in certain patients with cirrhosis of the liver.

3. Subnormal concentrations of proteins in the serum did not necessarily indicate subnormal quantities of total circulating proteins.

4. Clinical improvement was correlated with ability to maintain a normal quantity of total circulating albumin in four of the patients. It is suggested that this may be an important factor in determining prognosis in the cirrhotic patient.

5. It is possible for patients with advanced cirrhosis of the liver to show clinical improvement for long periods of time despite persistent impairment of liver function as determined by several hepatic function tests and despite the presence of subnormal concentrations of albumin in the serum.

\section{ACKNOWLEDGMENT}

Appreciation is expressed to Mrs. Dorothy L. Dezelia, R.T., for technical help in carrying out this study.

\section{BIBLIOGRAPHY}

1. Addis, T., Poo, L. J., and Lew, W., Protein loss from the liver during a two day fast. J. Biol. Chem., 1936, 115, 117.

2. Madden, S. C., and Whipple, G. H., Plasma proteins; their source, production and utilization. Physiol. Rev., 1940, 20, 194.

3. Whipple, G. H., Hemoglobin and plasma proteins; their production, utilization and interrelation. Am. J. M. Sc., 1942, 203, 477.

4. Whipple, G. H., and Hurwitz, S. H., Fibrinogen of the blood as influenced by the liver necrosis of chloroform poisoning. J. Exper. Med., 1911, 13, 136.

5. Foster, D. P., and Whipple, G. H., Blood fibrin studies. II. Normal fibrin values and the influence of diet. Am. J. Physiol., 1922, 58, 379.

6. Tumen, H., and Bockus, H. L., Clinical significance of serum proteins in hepatic diseases compared with other liver function tests. Am. J. M. Sc., 1937, 193, 788.

7. Post, J., and Patek, A. J., Jr., Serum proteins in cirrhosis of the liver. I. Relation to prognosis and to formation of ascites. Arch. Int. Med., 1942, 69, 67.

8. Drury, D. R., and McMaster, P. D., The liver as a source of fibrinogen. J. Exper. Med., 1929, 50, 569.

9. Jones, T. B., and Smith, H. P., The blood fibrinogen level in hepatectomized dogs and an outline of a method for the quantitative determination of fibrinogen. Am. J. Physiol., 1930, 94, 144.

10. Meek, W. J., Relation of the liver to the fibrinogen content of the blood. Am. J. Physiol., 1912, 30, 161. 
11. Metcoff, J., Favour, C. B., and Stare, F. J., Plasma protein and hemoglobin in protein-deficient rat: three dimensional study. J. Clin. Invest., 1945, $24,82$.

12. Lyons, R. H., Jacobson, S. D., and Neerkin, J. L., Relationship between changes in serum protein concentration and plasma volume in normal subjects. J. Lab. \& Clin. Med., 1945, 30, 404.

13. Perera, G. A., The plasma volume in Laennec's cirrhosis of the liver. Ann. Int. Med., 1946, 24, 643.

14. Hiller, G. I., Huffman, E. R., and Levey, S., Plasma volume and total circulating proteins in cirrhosis of the liver. J. Mich. State Med. Soc., 1948, 47, 529.

15. Gibson, J. G., 2nd, and Evans, W. A., Jr., Clinical studies of the blood volume. I. Clinical application of the method employing azo dye "Evans blue" and spectrophotometer. J. Clin. Invest., 1937, 16, 301.

16. Gibson, J. G., 2nd, and Evelyn, K. A., Clinical studies of the blood volume. IV. Adaptation of the method to the photoelectric microcolorimeter. J. Clin. Invest., 1938, 17, 153.

17. Gibson, J. G., 2nd, Clinical significance of the blood volume. Ann. Int. Med., 1941, 14, 2014.

18. Keith, N. M., Rowntree, L. G., and Geraghty, J. T., A method for the determination of plasma and blood volume. Arch. Int. Med., 1915, 16, 547.

19. Hawk, P. B., Bergheim, O., Oser, B. L., and Cole, A. G., Practical Physiological Chemistry. Blakiston, Philadelphia, 1937, Ed. 11, pp. 453.

20. Levey, S., A simple method of determining nonprotein nitrogen, total protein and albumin in blood serum samples by using Conway cells. Am. J. Clin. Path., 1948, 18, 435.

21. Ware, A. G., Guest, M. M., and Seegers, W. H., Fibrinogen: with special reference to its preparation and certain properties of the product. Arch. Biochem., 1947, 13, 231.

22. Bing, J., Naeser, J., Rasch, G., and Røjel, K., Serum proteins in normal people. Acta med. Scandinav., 1946, 126, 351.

23. Gregersen, M. I., and Gibson, J. G., Jr., Conditions affecting absorption spectra of vital dyes in plasma. Am. J. Physiol., 1937, 120, 494.

24. Gibson, J. G., 2nd, and Evans, W. A., Jr., Clinical studies of the blood volume. II. The relation of plasma and total blood volume to venous pressure, blood velocity rate, physical measurements, age and sex in ninety normal humans. J. Clin. Invest., 1937, $16,317$.

25. Gibson, J. G., 2nd, Clinical studies of the blood volume. VI. Changes in blood volume in pernicious anemia in relation to the hematopoietic response to intramuscular liver extract therapy. J. Clin. Invest., 1939, 18, 401.

26. Heller, H., and Urban, F. F., The fate of antidiuretic principle of posterior pituitary extracts in vivo and in vitro. J. Physiol., 1935, 85, 502.

27. Lloyd, C. W., and Williams, R. H., Endocrine changes associated with Laennec's cirrhosis of the liver. Am. J. Med., 1948, 4, 315.

28. Robinson, F. H., Jr., and Farr, L. E., The relation between clinical edema and the excretion of an antidiuretic substance in the urine. Ann. Int. Med., 1940, 14, 42.

29. Ralli, E. P., Robson, J. S., Clarke, D., and Hoagland, C. L., Factors influencing ascites in patients with cirrhosis of the liver. J. Clin. Invest., 1945, 24, 316.

30. Furth, J., and Sobel, H., Cited by Labby, D. H., and Hoagland, C. L., Water storage and movements of body fluids and chlorides during acute liver disease. J. Clin. Invest., 1947, 26, 343.

31. Farnsworth, E. B., Electrolyte partition in patients with edema of various origins. Am. J. Med., 1948, 4, 338.

32. Berman, L., Axelrod, A. R., Jacobson, S. D., Horan, T. N., Vonderheide, E. C., and Sharp, E. A., The blood and bone marrow in patients with cirrhosis of the liver. Proc. Cent. Soc. Clin. Res., 1948, 21, 75.

33. Muntwyler, E., Clinical significance of serum protein (albumin and globulin) changes. J. Lab. \& Clin. Med., 1945, 30, 526.

34. To be reported. 